\title{
Peranan Penyuluh Pertanian Lapangan Dalam Pembuatan Pupuk Organik Padat \\ (Kasus pada Kelompok Ternak Putra Kertha Santhi, Lingkungan Kebon, Kelurahan Baler Bale Agung, Kecamatan Negara, Kabupaten Jembrana)
}

\author{
NI KOMANG MAYA GITA SMARA, I DEWA PUTU OKA SUARDI, \\ I DEWA GEDE AGUNG
}

\author{
Program Studi Agribisnis, Fakultas Pertanian, Universitas Udayana \\ J1. PB. SudirmanDenpasar 80323 \\ Email: gita_smara@yahoo.co.id \\ okasuardi@yahoo.com
}

\begin{abstract}
Role of Field Agricultural Extension Officer in Solid Organic Fertilizer Production, (In the case of Putra Kertha Santhi Group, Kebon - Baler Bale Agung Village, Negara District Jembrana Regency)
\end{abstract}

\begin{abstract}
An agricultural extension officer is the agent of change in farmer's behaviors. He does this by encouraging farmers to change their behaviors to be farmers with better skills and farmers who be able to make their own decisions, which in turn will lead them into achieving a better life. The importance of the role of facilitator (Field Agricultural Extension Officer) and the importance of innovation delivered by him, facilitator should be able to become a leader who can develop and improve the ability of farmers in a joint effort to change their lives for the better. This study aimed to identify the role of field extension officer in solid organic fertilizer production either as a communicator, counselor, facilitator, organizer or motivator. This study took place in Putra Kertha Santhi Group. The research sites were selected by using purposively sampling. The respondents were chosen by using census method in accordance with the number of farmer group members which is 20 people. Method used in this study was descriptive qualitative analysis, which is a research aiming to provide an overview and explanation of the variables examined. The result showed that the role of field agricultural extension officer in the manufacture of solid organic fertilizer in Putra Kertha Santhi Group is good with the score of 83.4\%. This means that the extension officer on duty in Baler Bale Agung Village has been able to carry out his role as a communicator, counselor, facilitator, organizer and motivator.
\end{abstract}

Keywords: role, organic, fertilizer, farmer 


\section{Pendahuluan}

\subsection{Latar belakang}

Penyuluh pertanian merupakan agen bagi perubahan perilaku petani, yaitu dengan mendorong masyarakat petani untuk mengubah perilakunya menjadi petani dengan kemampuan yang lebih baik dan mampu mengambil keputusan sendiri, yang selanjutnya akan memperoleh kehidupan yang lebih baik (Kartasapoetra, 1994). Tugas pokok penyuluh pertanian adalah menyuluh, selanjutnya dalam menyuluh dapat dibagi menjadi menyiapkan, melaksanakan, mengembangkan, mengevaluasi, dan melaporkan kegiatan penyuluhan (Badan Pengembangan SDM Pertanian, 2010). Petani yang dibina bergairah dan bersemangat untuk berusaha mencapai cita-cita kehidupan, maka PPL juga harus berfungsi sebagai motivator yang tangguh atau orang yang membangkitkan motivasi masyarakat yang dibinanya dalam tugas sebagai penyuluh pertanian. PPL juga merupakan fasilitator yang membantu petani untuk melaksanakan proses usahataninya(Zulkarimein, 1990).

Kelompok tani merupakan organisasi yang dapat dikatakan berfungsi dan ada secara nyata, di samping berfungsi sebagai wahana penyuluhan dan penggerak kegiatan anggotanya. Beberapa kelompok tani juga mempunyai kegiatan lain, seperti gotong royong, usaha simpan pinjam dan arisan kerja untuk kegiatan usahatani (Hermanto, 2007). Kelompok Ternak Putra Kertha Santhi merupakan program bantuan Pengembangan Pertanian Terpadu (Pepadu) dari Pemkab Jembrana, terbentuk pada tanggal 9 Januari 2012. Anggota kelompok ternak selama ini sudah melakukan kegiatan dalam pengolahan pupuk organik padat dari limbah kotoran sapi. Pupuk yang dihasilkan kelompok mencapai 4.704 kg setiap 25 hari. Kelompok Ternak Putra Kertha Santhi telah memanfaatkan limbah kotoran sapi yang menumpuk disekitar kandang dan mampu membuat pupuk organik padat secara mandiri.Peran penyuluh didalamnya mempermudah Kelompok Ternak Putra Kertha Santhi untuk menemukan solusi dari masalah limbah ternak yang menumpuk, dan tidak dimanfaatkan oleh petani. Penyuluh membantu petani dalam pendistribusian pupuk dengan mencarikan distributor pupuk untuk membeli pupuk hasil olahan Kelompok Ternak Putra Kertha Santhi.Berdasarkan uraian tersebut, maka menarik untuk dikaji peranan penyuluh pertanian lapangan dalam pembuatan pupuk organik padat.

\subsection{Rumusan Masalah}

Bagaimana peranan penyuluh pertanian lapangan (PPL) dalam pembuatan pupuk organik padat di Kelompok Ternak Putra Kertha Santhi, Lingkungan Kebon, Kelurahan Baler Bale Agung, Kecamatan Negara, Kabupaten Jembrana?

\subsection{Tujuan Penelitian}

Untuk mengetahui peranan PPL dalam pembuatan pupuk organik padat di Kelompok Ternak Putra Kertha Santhi, Lingkungan Kebon, Kelurahan Baler Bale Agung, Kecamatan Negara, Kabupaten Jembrana. 


\section{Metode Penelitian}

\subsection{Lokasi dan Waktu Penelitian}

Penelitian ini dilakukan di Kelompok Ternak Putra Kertha Santhi, Lingkungan Kebon, Kelurahan Baler Bale Agung, Kecamatan Negara, Kabupaten Jembrana. Pertimbangan pemilihan lokasi penelitian adalahKelompok Ternak Putra Kertha Santhi merupakan kelompok yang aktif dalam proses pembuatan pupuk organik padat dan menjadi produsen pupuk terbesar di Kecamatan Negara. Penelitian ini dilaksanakan dari bulan Januari 2016 s.d. April 2016.

\subsection{Populasi, Responden, dan Informan Kunci}

Populasi penelitian ini adalah seluruh anggota aktif Kelompok Ternak Putra Kertha Santhi yang berjumlah 20 orang.Responden adalah orang-orang yang merespon atau menjawab pertanyaan penelitian baik peranyaan tertulis maupun lisan (Arikunto, 2003). Penentuan dilakukan dengan metode sensus, sehingga seluruh anggota aktif Kelompok Ternak Putra Kertha Santhi dijadikan sebagai responden. Informan kunci dalam penelitian ini adalah Ketua Kelompok Ternak Putra Kertha Santhi dan PPL Desa Baler Bale Agung.

\subsection{Jenis dan Sumber Data}

Jenis data dalam penelitian ini adalah data kualitatif dan kuantitatif, sumber data terdiri atas data primer dan data sekunder. Data primer adalah data yang diperoleh dengan survei lapangan yang menggunakan semua metode pengumpulan data original, sedangkan data sekunder adalah data yang telah dikumpulkan oleh lembaga pengumpulan data dan dipublikasikan kepada masyarakat pengguna data(Kuncoro, 2003). Data primer dilakukan dengan metode survei, yaitu dengan cara mendatangi serta mewawancarai responden dengan menggunakan daftar pertanyaan yang telah disiapkan untuk mengetahui ciri-ciri kelompok tani responden yang terdiri atas variabel umur, jenis kelamin, pendidikan, jumlah anggota rumah tangga, pekerjaan sampingan dan peranan penyuluh pertanian lapangan sebagai komunikator, pembimbing, fasilitator, organisator, dan dinamisator. Data sekunder digunakan untuk mengetahui keadaan umum daerah penelitian terdiri atas 1) letak geografis dan luasnya, 2) keadaan penduduk, dan 3) sarana dan lembaga yang ada. Data ini didapatkan di Kelurahan Baler Bale Agung dan Instansi yang terkait.

\subsection{Variabel dan Pengukuran}

Variabel digunakan untuk mengetahui peranan penyuluh pertanian lapangan dalam pembuatan pupuk organik padat dengan beberapa indikator yaitu komunikator, pembimbing, fasilitator, organisator, dan dinamisator. Semua indikator diukur dengan pemberian skor. Skor 1 merupakan skor minimum dan skor 5 merupakan skor maksimum. Skor yang telah diperoleh selanjutnya akan 
didistribusikan dalam kategori atau kelas dengan menggunakan rumus interval kelas.Interval yang diperoleh sebesar $16 \%$.

\subsection{Analisis Data}

Data yang terkumpul dalam penelitian ini dianalisis dengan menggunakan metode analisis deskriptif kualitatif. Hasil analisis dan intepretasi data disajikan dalam bentuk narasiyang disusun secara sistematis.

\section{Hasil dan Pembahasan}

\subsection{Profil Penyuluh Pertanian}

PPL yang bertugas di Kelurahan Baler Bale Agung Kecamatan Negara bernama Sayu Putu Ratih, S.PKP (NIP. 196208071989032 011). Lahir di Negara, pada Tanggal 7 Agustus 1962, pendidikan terakhirnya Sarjana Penyuluhan Komunikasi Pertanian di Universitas Terbuka. Pekerjaannya sebagai PPL sudah digeluti dari tahun 1991 hingga sekarang. Wilayah Kerja Penyuluh Pertanian (WKPP) yang pernah dibina adalah Desa Kaliakah, Desa Dangin Tukadaya, Sangkar Agung, Air Kuning, Perancak, Dauhwaru, Baluk, dan terakhir di Kelurahan Baler Bale Agung hingga saat ini. Program yang pernah dilaksanakan di Kelurahan Baler Bale Agung, diantaranya meliputi pemupukan berimbang pada padi, sistem tanam padi tabela (tanam benih langsung), metode SRI (system of rice intensification), budidaya jagung dan kedelai, pengendalian hama penyakit padi, manfaat limbah sapi baik padat maupun cair dan teknik pembuatannya, panen dan sanitasi terhadap tanaman kakao.

Kendala yang dihadapi penyuluh dalam proses penyuluhan adalah kehadiran petani dalam setiap penyuluhan hanya mencapi $60 \%$ sampai dengan $75 \%$, sedangkan yang diharapkan semua petani dapat hadir dalam setiap penyuluhan agar tujuan penyuluhan pertanian dapat tercapai secara optimal. Seperti yang dinyatakan oleh Rasyid (2001) belum optimalnya peranan penyuluhan pertanian dapat disebabkan oleh rendahnya tingkat partisipasi petani terhadap penyuluh pertanian sebagai akibat rendahnya mutu pelayanan penyuluhan pertanian.

\subsection{Peranan PPL dalam Pembuatan Pupuk Organik Padat}

Peranan merupakan aspek dinamis kedudukan (status). Apabila seseorang melaksanakan hak dan kewajibannya sesuai dengan kedudukannya, maka ia menjalankan suatu peranan. Peranan juga merupakan penilaian sejauh mana fungsi seseorang atau bagian dalam menunjang usaha pencapaian tujuan yang ditetapkan atau ukuran mengenai hubungan dua variabel yang mempunyai sebab akibat (Soekanto, 2002). Hasil penelitian menunjukkan bahwa peranan PPL dalam pembuatan pupuk organik padat tergolong dalam kategori baik dengan pencapaian skor $83,4 \%$. Pencapaian skor terendah pada indikator pembimbing mencapai kategori skor baik $(81,8 \%)$. Berikut disajikan hasil penelitianperanan PPL dalam pembutan pupuk organik padat pada tabel 1 . 
Tabel 1.

Peranan Penyuluh Pertanian Lapangan dalam Pembuatan Pupuk Organik Padat pada Kelompok Ternak Putra Kertha Santhi, Tahun 2016

\begin{tabular}{clcc}
\hline No. & \multicolumn{1}{c}{ Variabel } & Pencapaian Skor (\%) & Kategori \\
\hline 1. & Penyuluh sebagai Komunikator & 85,9 & Sangat Baik \\
2. & Penyuluh sebagai Pembimbing & 82,1 & Baik \\
3. & Penyuluh sebagai Fasilitator & 84,0 & Baik \\
4. & Penyuluh sebagai Organisator & 83,4 & Baik \\
5. & Penyuluh sebagai Dinamisator & 82,2 & Baik \\
\hline & Peranan PPL & 83,5 & Baik \\
\hline
\end{tabular}

Hal ini berarti penyuluh yang bertugas di Kelurahan Baler Bale Agung, Kecamatan Negara, Kabupaten Jembrana sudah mampu berperan dengan baik meskipun dalam kegiatannya mengalami hambatan-hambatan, namun penyuluh masih mampu mengatasi hambatan tersebut. Penyuluh Pertanian Lapang dapat menjalankan perannya sebagai komunikator, pembimbing, fasilitator, organisator, dan dinamisator dengan baik pada Kelompok Ternak Putra Kertha Santhi.

\subsubsection{Penyuluh sebagai komunikator}

Penyuluh sebagai komunikator dalam sebuah penyuluhan adalah orang yang tugasnya menyampaikan pesan, apakah itu pesan pembangunan dalam artian yang lebih umum ataupun pesan khusus tentang suatu inovasi pertanian untuk mengubah perilaku petani. Empat faktor pada sumber yang dapat meningkatkan ketepatan komunikasi, yaitu: keterampilan berkomunikasi, sikap mental, tingkat pengetahuan, dan posisi dalam sistem sosial budaya (Yuhana, 2008).Hasil penelitian peranan PPL dalam pembuatan pupuk organik padat sebagai komunikator diperoleh kategori sangat baik dengan pencapaian skor $85,9 \%$. Berikut disajikan hasil penelitianperanan PPL sebagai komunikator pada tabel 2.

Tabel 2.

Peran PPL sebagai Komunikator, pada Kelompok Ternak Putra Kertha Santhi, Tahun 2016.

\begin{tabular}{llcc}
\hline & \multicolumn{1}{c}{ Indikator } & $\begin{array}{c}\text { Pencapaian skor } \\
(\%)\end{array}$ & Kategori \\
\hline 1 & Keahlian penyampaian informasi & 89,0 & Sangat Baik \\
2 & Pemahaman penyuluh terhadap materi & 85,0 & Sangat Baik \\
3 & Bahasa yang digunakan penyuluh & 91,0 & Sangat Baik \\
4 & Hubungan personal penyuluh dengan kelompok tani & 83,0 & Baik \\
5 & Kebaruan informasi yang disampaikan & 80,0 & Baik \\
6 & Komunikasi penyuluh dengan kelompok tani & 89,0 & Sangat Baik \\
7 & Komunikasi penyuluh saat berdiskusi & 81,0 & Baik \\
8 & Komunikasi tatap muka penyuluh dengan kelompok tani & 89,0 & Sangat Baik \\
\hline & Peranan PPL sebagai komunikator & 85,9 & Sangat Baik \\
\hline
\end{tabular}

Pencapaian skor tertinggi adalah bahasa yang digunakan penyuluh saat kegiatan penyuluhan mencapai kategori sangat baik dengan pencapain skor 
91,0\%.Hasil wawancara yang sudah dilaksanakan, pencapaian skor yang diperoleh pada bahasa yang digunakan, PPL menggunakan bahasa daerah setempat yaitu bahasa daerah (Bali) sehingga informasi yang disampaikan mudah dimengerti petani. Alat bantu yang digunakan penyuluh pada kelompok ternak Putra Kertha Santhi adalah audio visual seperti microphonealat tulis seperti papan tulis, spidol, alat peraga seperti leaflet. Alat bantu tersebut digunakan penyuluh untuk penyuluhan pembuatan pupuk organik padat sehingga petani lebih mudah memahami materi penyuluhan.

\subsubsection{Penyuluh sebagai pembimbing}

Berdasarkan hasil penelitian peranan penyuluh pertanian dalam pembuatan pupuk organik padat sebagai pembimbing diperoleh kategori baik dengan pencapaian skor $82,1 \%$. Berikut data akan dirincikan pada tabel 3 .

\section{Tabel 3.}

Peranan PPL sebagai Pembimbing, pada Kelompok Ternak Putra Kertha Santhi, Tahun 2016

\begin{tabular}{llcc}
\hline & \multicolumn{1}{c}{ Indikator } & Pencapaian skor (\%) & Kategori \\
\hline 1 & Bimbingan cara pemakaian alat pembuatan pupuk & 80,0 & Baik \\
2 & Bimbingan kualitas bahan pembuatan pupuk & 81,0 & Baik \\
3 & Bimbingan jenis bahan pembuatan pupuk & 84,0 & Sangat Baik \\
4 & Bimbingan proses pengemasan pupuk & 78,0 & Baik \\
5 & Bimbingan cara pembuatan pupuk organik padat & 84,0 & Baik \\
6 & Bimbingan dalam mengelola sumber dana & 85,0 & Sangat Baik \\
7 & Bimbingan mengenai perkembangan kebutuhan & 83,0 & Baik \\
& petani yang berasal dari lembaga atau instansi & 82,1 & Baik \\
\hline
\end{tabular}

Seorang penyuluh adalah pembimbing dan guru bagi petani dalam pendidikan non formal, penyuluh memiliki gagasan yang tinggi untuk mengatasi hambatan dalam pembangunan pertanian yang berasal dari petani maupun keluarganya.Penyuluh harus mampu memberikan praktek demontrasi tentang suatu cara atau metode pembuatan pupuk organik padat. Bimbingan dalam mengelola sumber danamemperoleh skor tertinggi dengan kategori sangat baik dan mencapai skor $85,0 \%$. Hasil wawancara, penyuluh mampu memberikan bimbingan kepada petani tentang sumber dana kredit yang dapat digunakan untuk mengembangkan usaha tani mereka dan mengikuti perkembangan terhadap kebutuhan petani yang berasal dari instansi terkait. Penyuluh terbuka memberikan bimbingan dalam pembukuan khas kelompok dan uang hasil penjualan pupuk disimpan di LPD Baler Bale Agung yang disarankan oleh penyuluh. Hasil penjualan pupuk organik padat perbulan mencapai Rp 2.822.400 dengan $4.704 \mathrm{~kg}$ pupuk padat. 


\subsubsection{Penyuluh sebagai fasilitator}

Hasil penelitian peranan penyuluh pertanian dalam pembuatan pupuk organik padat sebagai fasilitator diperoleh kategori baik dengan pencapaian skor $84 \%$. Peran sebagai fasilitator yang sangat baik ditandai pada indikatormemfasilitasi dalam menjual pupukdengan pencapaian skor sebesar 91,0\%. Berikut data masing-maisng indikator tampak pada tabel 4.

Tabel 4.

Peranan PPL sebagai Fasilitator, pada Kelompok Ternak Putra Kertha Santhi, Tahun 2016.

\begin{tabular}{|c|c|c|c|}
\hline \multicolumn{2}{|r|}{ Indikator } & Pencapaian skor $(\%)$ & Kategori \\
\hline 1 & Memfasilitasi dalam menjual pupuk & 91,0 & Sangat Baik \\
\hline 2 & Memfasilitasi materi penyuluhan & 83,0 & Baik \\
\hline 3 & $\begin{array}{l}\text { Memfasilitasi dalam persedian alat dan bahan } \\
\text { pembuatan pupuk }\end{array}$ & 84,0 & Baik \\
\hline 4 & Membantu petani mengatasi masalah & 85,0 & Sangat Baik \\
\hline 5 & $\begin{array}{l}\text { Memfasilitasi dalam menjalin } \\
\text { penguatan modal }\end{array}$ & 81,0 & Baik \\
\hline 6 & Memfasilitasi petani untuk berdiskusi & 80,0 & Baik \\
\hline & Peran PPL sebagai Fasilitator & 84,0 & Baik \\
\hline
\end{tabular}

Kegiatan penyuluhan sangat berkaitan dengan kegiatan fasilitasi, terutama dalam memfasilitasi petani terhadap hal-hal yang berhubungan dengan usahatani yang ditekuni. Berdasarkan hasil wawancara, penyuluh telah terbiasa memfasilitasi petani, terutama dalam menjual pupuk organik padat hasil olahan kelompok ternak Putra Kertha Santhi ke distributorpupuk, KUD, dan penjual tanaman sekitar kota Negara. Penyuluh juga menyarankan kepada kelompok tani agar menggunakan pupuk tersebut dalam berusahatani.

Tugas penyuluh pertanian sebagai fasilitator sudah dilakukan dengan baik selalu mencarikan distributor pupuk, menyediakan narasumber serta materi penyuluhan, hal ini sudah sesuai dengan apa yang disampaikan oleh Kartasapoetra (1988), bahwa sebagai fasilitator, penyuluh bertanggung jawab untuk menyediakan lingkungan belajar yang memadai, efektif, serta kemudahan lain yang akan mempermudah berlangsungnya suatu proses yang aktif.

\subsubsection{Penyuluh sebagai organisator}

Penyuluh sebagai organisator, berusaha untuk menjalin hubungan baik dengan segenap lapisan masyarakat, menumbuhkan kesadaran dan menggerakkan partisipasi masyarakat, mengarahkan dan membina kegiatan maupun mengembangkan kelembagaan untuk melaksanakan perubahan-perubahan yang direncanakan.Hasil penelitian peranan penyuluh pertanian dalam pembuatan pupuk organik padat sebagai organisator diperoleh kategori baik dengan pencapaian skor $83,4 \%$. Data masing-masing indikator tertuang pada tabel 5 . 
Tabel 5.

Peranan PPL sebagai Organisator, pada Kelompok Ternak

Putra Kertha Santhi, Tahun 2016

\begin{tabular}{clcc}
\hline & \multicolumn{1}{c}{ Indikator } & Pencapain skor (\%) & Kategori \\
\hline 1 & Mengatur kelompok tani untuk mau berkumpul bersama & 81,0 & Baik \\
2 & Mengorganisasikan kelompok tani menjadi organisasi & 89,0 & Sangat \\
& kelompok yang berkembang & & Baik \\
3 & Mengatur kelompok tani untuk membuat pupuk organik & 80,0 & Baik \\
4 & Menyusun jadwal kerja pembuatan pupuk organik & 83,0 & Baik \\
5 & Mengorganisir waktu pekerjaan & 84,0 & Baik \\
\hline$\quad$ Peran PPL sebagai Organisator & 83,4 & Baik \\
\hline
\end{tabular}

Hasil wawancara, penyuluh melakukan aktivitas utama antara lain mendorong kebersamaan sesama anggota, dan mendorong aktivitas sesuai peranan. Artinya, penyuluh mendorong keberadaan kelompok dalam masyarakat petani agar tetap dipertahankan dan tetap berkembang, dengan adanya dorongan oleh penyuluh untuk terus berkembang, anggota kelompok ternak merasakan manfaat yang didapat seperti bertukar informasi, berinteraksi, dan bersosialisasi terkait dengan kegiatan pembuatan pupuk organik padat.

\subsubsection{Penyuluh sebagai dinamisator}

Penyuluh sebagai dinamisator harus mampu memberikan dorongan terhadap petani tentang usaha pembuatan pupuk organik padat yang menguntungkan, serta membantu merencanakan kegiatan pengolahan pupuk yang menguntungkan dengan segala kendalanya. Hasil penelitian peranan penyuluh pertanian dalam pembuatan pupuk organik padat sebagai dinamisator diperoleh kategori baik dengan pencapaian skor $82,2 \%$. Berikut data akan tersaji pada tabel 6 .

Tabel 6.

Peranan PPL sebagai Dinamisator, pada Kelompok Ternak Putra Kertha Santhi, Tahun 2016

\begin{tabular}{clcc}
\hline \multicolumn{1}{c}{ Indikator } & Pencapaian skor (\%) & Kategori \\
\hline 1 & $\begin{array}{l}\text { Menggerakkan kelompok tani untuk tahu proses } \\
\text { pembuatan pupuk organik padat }\end{array}$ & 89,0 & $\begin{array}{c}\text { Sangat } \\
\text { Baik }\end{array}$ \\
2 & $\begin{array}{l}\text { Menggerakkan kelompok tani untuk mampu membuat } \\
\text { pupuk secara mandiri }\end{array}$ & 83,0 & Baik \\
3 & $\begin{array}{l}\text { Menggerakkan kelompok tani agar berperan aktif } \\
\text { dalam kegiatan mengolah pupuk organik }\end{array}$ & 78,0 & Baik \\
4 & $\begin{array}{l}\text { Menggerakkan petani untuk mau menerima } \\
\text { perkembangan teknologi }\end{array}$ & 81,0 & Baik \\
5 & Mengembangkan inovasi pupuk organik & 80,0 & Baik \\
\hline & Peran PPL sebagai dinamisator & 82,2 & Baik \\
\hline
\end{tabular}

Berdasarkan Tabel 6, pencapaian skor tertinggi adalah indikator menggerakkan kelompok tani untuk tahu proses pembuatan pupuk organik padatyang termasuk dalam kategori sangat baik dan mencapai skor $89,0 \%$. Hasil wawancara kepada petani responden, penyuluh selalu mendorong petani untuk terus berinovasi 
tentang pembuatan pupuk organik padat saat melakukan kunjungan. Anggota Kelompok Ternak Putra Kertha Santhi sudah termotivasi oleh dorongan PPL untuk terus berlanjut mengolah pupuk organik padat, dan hingga saat ini Kelompok Ternak Putra Kertha meneruskan pembuatan pupuk organik padat dan menjadi produsen pupuk terbesar di Kecamatan Negara. Penyuluh sebagai dinamisator harus beraktivitas utama antara lain (1) mendorong usaha berencana dan terukur, dan (2) mendorong pilihan usaha yang lebih menguntungkan (Jarnie, 1994).

\section{Simpulan dan Saran}

\subsection{Simpulan}

Berdasarkan hasil penelitian dapat disimpulkan bahwa, peranan PPL membina kelompok tani dalam pembuatan pupuk organik padat pada Kelompok Ternak Putra Kertha Santhi termasuk kategori baik dengan pencapaian skor 83,5\%. Peran PPL tersebut meliputi: (1) Peran sebagai komunikator tergolong kategori sangat baik dengan pencapaian skor $85,9 \%$, (2) Peran sebagai pembimbing mencapai skor $82,1 \%$ dengan kategori baik, (3) Pencapaian skor pada peran penyuluh sebagai fasilitator memperoleh skor $84,0 \%$ dengan kategori baik, (4) Peran sebagai organisator mencapai kategori baik dengan pencapaian skor $83,4 \%$, dan(5) Penyuluh sebagai dinamisator memperoleh kategori baik dan mencapai skor $82,2 \%$.

\subsection{Saran}

Saran yang dapat diberikan terkait dengan penelitian yang telah dilakukan adalah peran penyuluh pertanian dalam pembuatan pupuk organik padat sudah dinilai baik oleh Kelompok Ternak Putra Kertha Santhi, namun dalam perannya sebagai pembimbing dalam bimbingan proses pengemasan perlu ditingkatkan agar petani lebih terampil dalam pengemasan pupuk. Penyuluh juga diharapkan lebih memfasilitasi petani dalam berdiskusi agar petani dapat saling bertukar pikiran dan menemukan solusi terhadap masalah-masalah yang dihadapi. Peran penyuluh sebagai organisator, dan dinamisator juga perlu ditingkatkan sehingga petani lebih termotivasi dalam pembuatan pupuk organik. Peran penyuluh lebih dirasakan manfaatnya oleh petani yang tergabung pada Kelompok Ternak Putra Kertha Santhi.

\section{Ucapan Terima Kasih}

Terima kasih kepada Kelompok Ternak Putra Kertha Santhi yang telah meluangkan waktu untuk penulis mengadakan penelitian, Sayu Putu Ratih selaku penyuluhdi Kelurahan Baler Bale Agung dari BPP Kecamatan Negara atas bantuannya dalam memberikan materi studi pustakadan meluangkan waktu dalam berdiskusi mengenai peran penyuluh pertanian lapangan.

\section{Daftar Pustaka}

Arikunto, Suharsimi. 2003. Prosedur Penelitian, Suatu Praktek. Jakarta: Bina Aksara. 
Badan Pengembangan Sumberdaya Manusia Pertanian. 2007. UU No. 16 tahun 2006 Tentang Sistem Penyuluhan Pertanian, Perikanan dan Kehutanan. Departemen Pertanian. Jakarta.

Hermanto. 2007. Rancangan Kelembagaan Tani dalam Implementasi Prima Tani Di Sumatera Selatan. Pusat Penelitian dan Pengembangan Sosial Ekonomi Pertanian. Bogor.

Jarmie, M. J. 1994. Sistem Penyuluhan Pembangunan Pertanian Indonesia. Program Pascasarjana. Institut Pertanian Bogor. Bogor.

Kuncoro. 2013. BAB III Metode Penelitian. Internet. (Artikel on_line). http://repository.unhas.ac.id/bitstream/handle/123456789/1717/BAB\%20III.d ocx? sequence=4. Diunduh pada tanggal 25 Januari 2015.

Kartasapoetra, G. 1994. Teknologi Penyuluhan Pertanian. Bina Aksara. Jakarta.

Nasution, Zulkarimein. 1990. Prinsip-Prinsip Komunikasi untuk Penyuluhan. Lembaga Penerbit Fakultas Ekonomi Universitas Indonesia, Jakarta

Rasyid, M.A. 2001. Sangat Diperlukan Kegiatan Penyuluhan Pertanian. Ekstensia. Vol 13 tahun VII. September 2001.

Soekanto, Soerjono. 2002. Teori Peranan, Jakarta, Bumi Aksara.

Yuhana, Ida. 2008. Dasar-Dasar Komunikasi: Bahan kuliah. IPB. 